- RESENHAS

REVIEWS 
136 


\title{
A questão do subdesenvolvimento revista à luz do pensamento furtadiano
}

\author{
Paula Meyer Soares Passanezi \\ Doutora em Economia de Empresas - FGV-SP; \\ Coordenadora de Ciências Econômicas; Professora de Macroeconomia \\ no curso de Ciências Econômicas - UNINOVE. \\ ppassanezi@uninove.br
}

O livro $A$ navegação venturosa - ensaios sobre Celso Furtado é realmente uma navegação literária em torno das principais obras escritas pelo estudioso paraibano ao longo destes últimos anos. A obra reúne artigos e ensaios escritos pelo economista e professor Francisco de Oliveira acerca de Furtado, em que realiza, com muita propriedade, uma investigação crítica dos pontos abordados em seus textos. Por meio da reconstituição de várias passagens das obras, Oliveira conduz o leitor a uma profunda reflexão sobre o estilo e as posições de Furtado durante períodos importantes da história brasileira, sobretudo entre os anos 30 e 50 .

Furtado é considerado um dos maiores economistas que o país já teve. Nascido em Pombal, Paraíba, em 1920, transferiu-se, aos 19 anos, para a cidade do Rio de Janeiro, onde trabalhou como jornalista. Mais tarde, formou-se em Direito e, em 1948, doutorou-se em Economia Colonial Brasileira pela Universidade de Paris. Nos anos 50, integrou o grupo de economistas da Organização das Nações Unidas (ONU), servindo à Comissão Econômica da América Latina (CEPAL), o que the rendeu a presidência do Grupo Misto Cepal-BNDE [Banco Nacional de Desenvolvimento Econômico] e a elaboração do Programa de Desenvolvimento para o Brasil. Foi o mentor da criação da Superintendência de
Desenvolvimento do Nordeste (SUDENE), órgão destinado ao desenvolvimento regional, do qual foi superintendente até 1964. Após o Golpe Militar, exilou-se no Chile e, em seguida, na França, onde permaneceu por vários anos como professor catedrático da cadeira Desenvolvimento Econômico na Universidade de Paris. Nas décadas de 80 e 90 , voltou à esfera estatal atuando como consultor econômico e Ministro de Estado da Cultura, durante o governo Sarney.

O livro ora resenhado pode ser subdividido em três grandes blocos: no primeiro, faz-se uma retrospectiva das idéias defendidas por Furtado em sua vida acadêmica e profissional; no segundo, propõe-se uma releitura de sua visão do papel do Estado nas economias periféricas e, finalmente, para completar essa 'viagem' furtadiana, Oliveira aborda a teoria de subdesenvolvimento proposta pelo economista paraibano e sua relevância para a construção de um debate saudável sobre o subdesenvolvimento dos países da América Latina.

Nos primeiros capítulos, mostra-se a gênese do pensamento furtadiano e as bases em que se assentou a teoria do subdesenvolvimento por ele desenvolvida. A questão do subdesenvolvimento é retratada como fruto de um desequilíbrio estrutural (da esfera produtiva) entre países centrais e periféricos, que acaba engendrando a corrosão dos 
meios de troca - a industrialização é considerada a única saída para o desenvolvimento nacional. Essa tese desenvolvimentista é desnudada por Oliveira, que faz questão de mostrar alguns de seus aspectos frágeis como a omissão da explicação da teoria monetária vis à vis à existência de trocas desiguais e à falência do multiplicador keynesiano quando se instaura a industrialização dos países periféricos.

Tais reflexões são retomadas nos capítulos seguintes, quando o economista pernambucano busca, nos textos do mestre, a explicação para tais incongruências. Para isso, relembra várias passagens da vida de Furtado, desde a sua atuação no governo, na década de 60 , quando se transforma em administrador e político mais voltado à adoção de estratégias de transformação da situação socioeconômica do país. Após o golpe militar, Furtado entra numa fase de introspecção e se ocupa mais em interpretar do que em enxergar a eficácia das idéias por ele desenvolvidas.

Nos capítulos seguintes, é feita uma memorável releitura da obra Formação econômica do Brasil (1959), na qual se demonstra a grandiosidade de sua interpretação acerca da participação do Estado na economia e na sociedade brasileiras, baseada no pensamento de direita que dominou o cenário intelectual até o fim da década de 30 . A direita intelectual de Furtado nunca dispôs de uma interpretação do Brasil, unicamente reproduzindo a noção de Estado advinda dos manuais liberais. Somente após a estatização e a campanha do petróleo, a ala esquerdista começou a observar a importância da atuação do Estado enquanto agente norteador do desenvolvimento
- e foi Celso Furtado, com a produção de um conhecimento distintivo, que orientou a relevância da atuação estatal.

Por fim, Oliveira retoma a teoria furtadiana sobre subdesenvolvimento para mostrar o alcance e influência desse pensamento originário do seio da CEPAL, nos debates acerca dos fatores internos e externos que levam os países à condição de subdesenvolvidos. Lembra que a ampliação desse conceito foi feita por Florestan Fernandes ao reconhecer os efeitos maléficos da globalização no processo de desenvolvimento das nações tidas como periféricas, pontuando que a reprodução do subdesenvolvimento associa-se a uma modernização comandada pelas antigas classes dominantes de base agrária, o que, por sua vez, dá origem a uma nova classe social, reprimida e guiada pelos agraristas, o que permite afirmar que "[...] o subdesenvolvimento é a forma de modernização econômica sem revolução burguesa." (Oliveira, p. 112).

Essa lacuna da teoria cepalina é reconhecida anos mais tarde por Furtado. Apesar das inúmeras críticas às teses de globalização, Oliveira toma o trabalho teórico-prático de Furtado como um dos pontos de partida para a compreensão da questão do subdesenvolvimento. $O$ resultado final é uma aula de teoria e história econômicas centradas nas experiências e teorizações daquele que, sem dúvida, está entre os maiores intelectuais nacionais e constitui, para estudantes e professores universitários, referência fundamental do pensamento econômico sobre desenvolvimento. 